\title{
The Disunity of the Ummah Become 73 Groups in Takhrij Al- Hadith Perspective
}

\author{
Abdul Rohman ${ }^{1 *}$, Mulyani Mudis Taruna ${ }^{2}$ \\ ${ }^{1}$ The Faculty of Social and Political Sciences, Jenderal Soedirman University \\ ${ }^{2}$ Office of Religious Research and Development, Ministry of Religious Affairs Republic \\ Indonesia \\ *rohman.mudis@gmail.com
}

\begin{abstract}
Abstrak: Sebuah Hadis menyatakan bahwa umat Islam akan terpecah menjadi 73 kelompok. Ketika Nabi Muhammad saw. masih hidup, semua masalah umat dapat dikembalikan kepadanya, sehingga tidak ada perpecahan. Akan tetapi, setelah dia meninggal, banyak masalah muncul. Peristiwa tahkim (arbitrase) sebagai upaya menyelesaikan perang Shiffin, malah memunculkan tiga kelompok besar, yaitu Syiah, Khawarij, dan Muawwiyah. Kelompok terakhir sering disebut sebagai ahlus Sunni. Kejadian-kejadian tersebut sering digunakan sebagai poin hukum, untuk munculnya berbagai kelompok agama dalam Islam saat ini. Penulisan penelitian ini menggunakan metode studi pustaka. Adapun hasil penelitian ini menyimpulkan, bahwa: a) Hadis mengenai "Perpecahan umat menjadi 73 kelompok", termasuk Hadis terkenal (popular), Hadis yang telah banyak disampaikan oleh banyak tokoh dan diketahui oleh masyarakat, b) Para perawi di setiap jalan atau sanad dilalui oleh Hadis mukharij, pada thabaqat tabi'in yaitu Abi Salamah dengan seorang sahabat bernama Abu Hurairah yang tidak diketahui pertemuannya, sehingga posisi Hadis ini tidak sampai pada tingkat sahih, karena itu tidak tersambung (ghoiru muttasil). Berdasarkan analisis al-Quran, Hadis, atau ushul, Hadis tentang perpecahan umat Islam ke dalam 73 kelompok, lebih baik tidak digunakan sebagai bahan rujukan utama dalam ceramah dan atau khotbah, karena membawa lebih banyak madarat daripada manfaatnya.
\end{abstract}

Keyword: perpecahan; toleransi; persatuan; sahih, thabaqat; umat

Abstract: A Hadith states that Muslims will disunity into 73 groups. When the Prophet was still alive all the problems of the Ummah could be returned to him, so there was no disunity. But after he died, many problems surfaced. The event of tahkim (arbitration) as an attempt to resolve the Shiffin war, instead gave rise to three major groups, namely the Shi'ite, Khawarij and Muawwiyah. The last group is often referred to as the ahlus Sunni. These events are often used as legal points, for the emergence of various religious groups in Islam today. The writing of this study uses the study literature method. As for the results of this study concluded, that: a) The Hadith concerning "The disunity of the people into 73 groups", included the famous Hadith (popular), the Hadith that has been widely delivered by many figures and the general public also knows it; b) The narrators on each path or sanad traversed by the mukharrij al Hadith, on thobaqat tabi'in namely Abi Salamah with a friend named Abu Hurairah unknown meeting, so the position of this Hadith is not up to the degree of saheeh, because it is not continued (ghoiru muttasil). Based on the Quran, Hadith, or ushul analysis, the Hadith about the disunity of Muslims into 73 groups, it is better not to be used as the main material in lectures and or sermons, because it brings more damage than the benefit.

Keyword: disunity; tolerance; unity; saheeh; thabaqat; ummah 


\section{A. Introduction}

Muslims often hear that a Hadith about Jews will be disunity into 71 groups. Christians will be disunity into 72 groups, while Muslims will be disunity into 73 groups. ${ }^{1}$ The divisions that occur among religious communities, it turns out when observing the disputes and conflicts that often occur in this world, shows that the Prophet's Hadith contains true predictions. There is even the possibility of a split which begins with the number 7 (seven) also shows the number or amount that is not limited. These Hadiths about "disunity" are often delivered through religious lectures, sermons in mosques and other events. This shows that this Hadith is quite well known by the Muslim community (famous). In fact, it is often used as a basis for justifying disunity in the ummah. Whereas disunity can destroy the joints of people's lives, such as helping, caring, and loving. No disunity on leads to peace, but each disunity will lead to hatred, hostility, revenge, prejudice, and even war that ends in killing each other.

When the Prophet Muhammad was still alive, all problems could be resolved thoroughly and the people were satisfied. Because he is the unity of command. However, after the Prophet's death, Muslims were confronted with a major defamation event, namely the Jamal war and the Shiffin war. The Jamal war a war in which Aisha as Rasulullah's exwife fought the caliph Ali bin Thalib, as her step-son-in-law. The Shiffin war is a war in which the caliph Ali against the Mu'awiyah group, the governor of Damascus. Efforts to resolve the Shiffin war are through tahkim (arbitration) occurred in $659 \mathrm{AD},{ }^{2}$ but these efforts have led to divisions among Muslims which are divided into three major groups namely Shi'ite, Khawarij and Muawwiyah. ${ }^{3}$

The events that occurred during the sahabat period were often used as legal points, if related to the emergence of various religious groups in Islam. Ahlus sunnah's hatred of the Wahabi group was caused by the Wahabi group being accused of being from the Khawarij. The Shi'ite group with ahlus sunnah has yet to reach a meeting point. Shi'ite groups with Wahhab groups also continue to be "hostile" to one another. Therefore, friction, animosity, conflict and even war between Muslim groups, are often arranged and returned to the event "tahkim". Although other trigger indicators play a role. Disputes also occur with internal religious groups. In Indonesia, almost all religious groups in Islam claim shelter under the ahlus sunnah wal jama'ah. But they often disagree with one group with another, so to be cause some disharmony, conflict and even disunity.

Some examples of religious social conflicts are cases of riots that occurred in several places in Indonesia, namely mutual hatred between Ahlus Sunnah with Salafi-Wahabi groups, which are often caused by heresy issues, ${ }^{4}$ conflicts between Muslims and

${ }^{1}$ Hadits no. 4596, Abi Dawud as-Sulaiman bin al-Asy'atsi as-Sijistaniy, Sunan Abi Dawud (Saudi Arabia: Bait al-Afkari ad-Dauiliyat, t.t.), p. 503.

${ }^{2}$ Philip K. Hitti, History of The Arabs (New York: Palgrave Macmillan, 2002), p.181.

${ }^{3}$ Anzar Abdullah, 'Radikalisme dalam Islam: Perspektif Historis: Radicalism in Islam, Historical Perspective,' Addin, 10.1(2016), p. 5-6. Harun Nasution, Islam Ditinjau Dari Berbagai Aspeknya 1 (Jakarta: UI Press, 1985), p. 95. Ahmad Atabik, 'Melacak Historis Syi'ah: Asal Usul Perkembangan dan AliranAlrannya', Fikrah: Jurnal Ilmu Aqidah dan Studi Keagamaan, 3.2(2015), p. 328.

4 Deni Hardiawan Putra, 'Fenomena Konflik Nahdlatul Ulama dan Salfi Gis Sunnah (Studi Kasus Di Perumahan Griya Indah Serpong, Gunung Sindur, Bogor', Skripsi, UIN Syarif Hidayatullah, 2018, p. 104. 
Ahmadiyah groups in Pandeglang, Banten, Parung, ${ }^{5}$ and or internal religious conflicts in Lombok. ${ }^{6}$ The trigger for conflict is not only because of differences in groups, but it could be due to political, ideological, power interest, and intolerance elements. This paper seeks to uncover the problem of divisions of the ummah through the approach of takhrij al-hadith. Disunity is often based on the "justification" revealed by the Prophet's Hadith about the division of the ummah into 73 groups. What is the position of the Hadith in terms of its validity? Is it proper to be a material for preaching and justification about the divisions of the people? To complete this study, the writer complement with a review of the Quran, Hadith, and ushul fiqh.

\section{B. Hadith Selection Method}

Takhrij al-hadith study is a literature study, which research through the steps of collecting, reading and recording literature/books to obtain data, and process it so as to facilitate in obtaining the purpose of this study. ${ }^{7}$ This study begins by searching for the Hadiths about the disunity of the Islamic ummah into 73 (seventy three) groups. First stage, looking for the book that contains the Hadith. Second, looking for a book that contains the entire sanad or narrators of the Hadith. Third, tracing the biography of the narrators of the Hadith sanad, whether continued or not. Fourth, studying the Hadith and finally to take conclusions.

The search of Hadiths about the disunity of Muslims into 73 groups can be practically opened in the Mu'jam al-Mufahras li Alfadzal-Hadith, by A.J. Wensinck. In this book there are four narrators who narrated it, namely Imam Abu Dawud, Imam Tirmidzi, Imam Ibn Majah and Imam Ahmad bin Hambal. The four narrators when the books were opened through "Maktabah as Syamilah", are found in the book of Imam Ahmad in his Musnad, juz 14, p.124; Sunan Ibn Majah, juz 2, p. 1321; Shahih wa Dha'if Sunan at Tirmidzi, juz 6, p. 140. As for the narrator Imam Abu Dawud, he did not find it in his Sunan. The Hadith has been discussed in the Maktabah Syamilah or included in 102 books, which include: the book "Musnad al maudhui al Jami 'lilkutubil' Asyrah, juz 2, p. 134 "; the book of Muhtashor Kitab al-'Itishom, juz 1, p. 121; Kitab al-'Itishom li Syatibi al-Hilali, juz 1, p. 98; the book of Tafsir al-Baghawi tafsir at-Turats, juz 2, p. 176; and or Majmu 'al-Fatawa, juz 16, p. 491.

\section{Matan and Sanad Hadith}

1. Matan Hadith

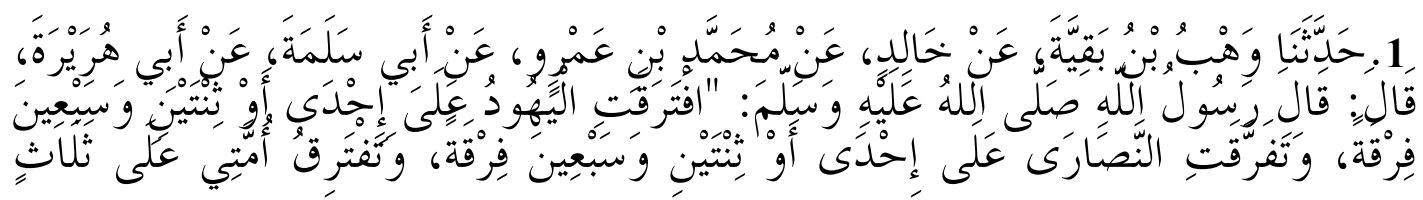

${ }^{5}$ Abdul Gaffar, 'Jamaah Ahmadiyah Indonesia (JAI) dalam Perspektif Kekerasan Negara: Dua Kasus Dari Surabaya Jawa Timur dan Lombok NTB,' Jurnal Sosiologi Islam, 3.2 (2013), p. 31.

${ }^{6}$ Saipul Hamdi, 'Politik Islah: Re-negoisasi Islah, Konflik, dan Kekuasaan dalam Nahdlatul Wathan Di Lombok Timur,' Kawistara, 1.1 (2011), p. 2.

${ }^{7}$ Khatibah, 'Penelitian Kepustakaan,' Jurnal Iqra, 5.1 (2011), p. 39. 


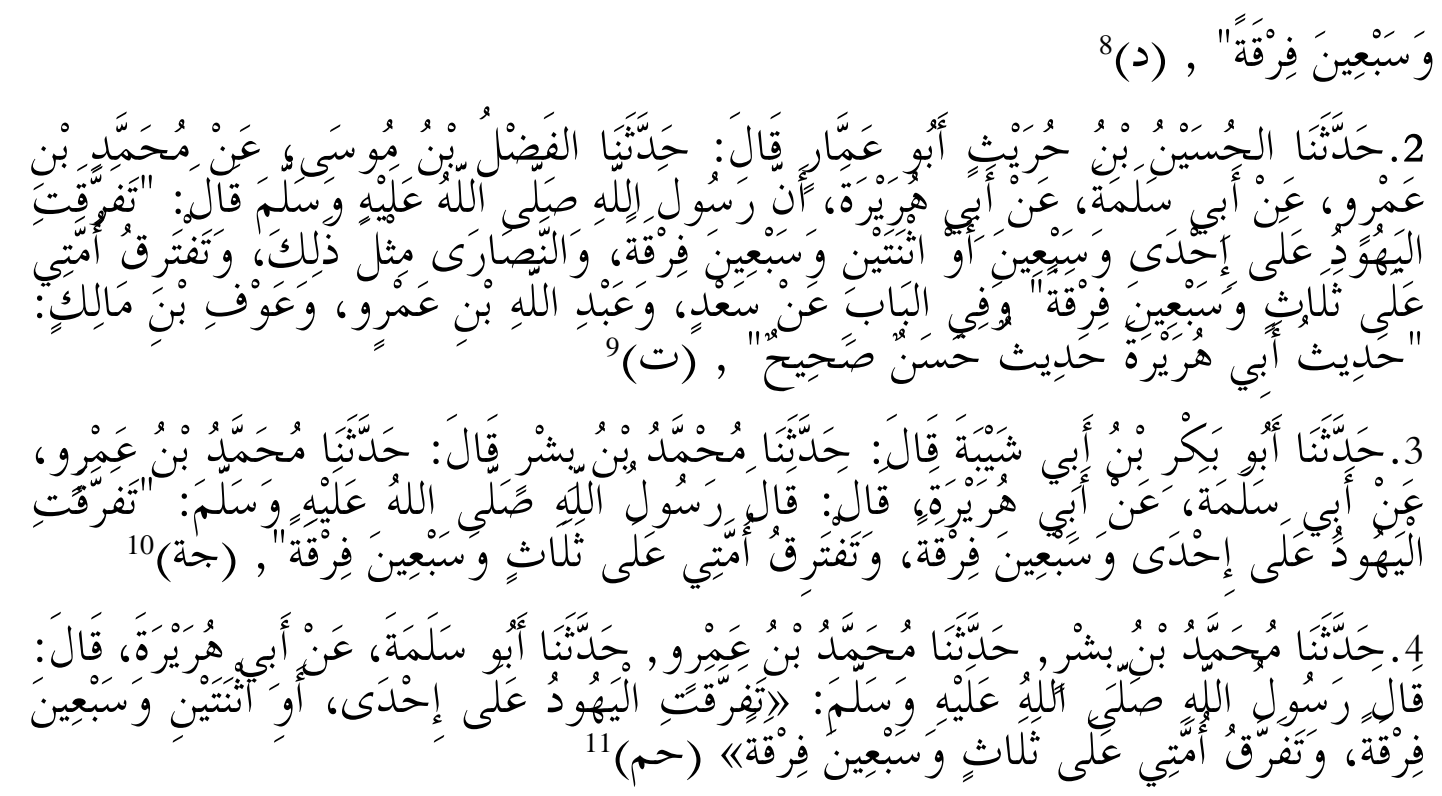

Matan Hadith translation, taken from the Hadith narrated by the priest Tirmidhi: "Jews will be divided into 71 or 72 groups, Christians will be divided as well as Jews, and my ummah will be divided into 73 groups".

\section{Sanad Each Hadith}

Sanad tracking between narrators is very important as an effort to find out their connection with one another. Sanad connection in the Hadith is one of the requirements that the Hadith is declared authentic. ${ }^{12}$ If they are not continued or not met, even if there is only one narrator, then the degree of validity of a Hadith is falls. Making a chart of each Hadith sanad is needed to know the position of the sanad or the narrators at each thabaqat. Are they in the first thabaqat, which is living in the Companions so they can meet with the Prophet Muhammad, or are they entering into a great tabi'in. Because there are narrators who lived during the tabi'in, tabiit tabi'in and after that time.

Chart making will also make it easier to find the level of narrators, whether they really meet each other or they live in one time, but different locations of the country, and or jurstru has never met, because when a narrator is born, the narrator called his teacher has died first therefore, it is necessary to make a chart. The sanad chart is made singly and contains each mukharij al Hadith (attached).

${ }^{8}$ Abi Dawud as-Sulaiman bin al-Asy'atsi as-Sijistaniy, Sunan Abi Dawud (Saudi Arabia: Bait al-Afkari ad-Dauiliyat, t.t.), p. 503.

${ }^{9}$ Abi 'Isa Muhammad bin 'Isa bin Saurah At-Tirmidzi, Jami'u at Tirmidzi (Saudi Arabia: Bait al-Afkari ad-Dauiliyat, t.t.), p. 428.

10 Abi 'Abdillah bin Muhammad bin Yazid bin Majah, As Sunan vol. 5 (Damaskus: Ar-Risalah al'Alamiyah, t.t.), p. 128.

${ }^{11}$ Imam Ahmad, Musnad al Imam Ahmad bin Hambal vol. 2, p. 332.

${ }^{12}$ Nasir Akib, 'Kesahihan Sanad dan Matan Hadits: Kajian Ilmu Ilmu Sosial,' Shaautut Tarbiyah, 15.1 (2009), 106. 


\section{a. Sanad Path of Imam Abu Dawud (202 - 275 H.)}

His full name is Sulaiman bin Ash'ats ibn Shadad ibn 'Amr Ibn Amir al Azdi as Sajistani. He is better known by the name Abu Dawud. He is a mukharij Hadith figure in this sanad line. He is a very thorough Hadith priest, a prominent figure in the Hadith experts and author of the sunan book. He was born in 202 H/817 AD in Sajistan and died in Basrah on 16 Syawal 275 H/889 AD. Since Abu Dawud was a child, he was a lover of knowledge and was friendly with the scholars to receive the knowledge he wanted. Before he grew up he had performed rihlah ilmiyah and studied Hadith to various countries such as, Hijaz, Sham, Egypt, Iraq, Khurasan and other countries. The results of the twinning were concretized by filtering the Hadiths and then writing them in the book of sunan. In Baghdad he taught the Hadith and fiqh to the inhabitants by using the book sunan as the main reference. The sunan book received great praise from Imam Ahmad bin Hambal. Imam Abu Dawud then settled in Basrah at the request of the governor of Basrah. ${ }^{13}$

He has several teachers including: Ahmad bin Hambal al-Qan'abi; Abu 'Amr ad-Darir; Muslim bin Ibrahim; Abdullah bin Raja; Imran bin Maysarah; Abi Bakr Abdullah bin Muhammad bin Abi Shaybah; Uthman bin Muhammad bin Abi Shaybah; Abu al-Walid atTayalisi; Qutaibah bin Sa'id; Muhammad bin Ahmad bin Abi Kholaf al-Baghdadi; Abi alJamahir Muhammad bin Sufyan at-Tanuhi; Muhammad bin Wair al-Mishri; Hisham bin 'Ammar ad-Dimsyaqi; and or Muhammad bin al-Wazir ad-Dimsyaqi. Mu'ad bin Asad alMarwazi.

As for his students, among others: Abu Isa at-Tirmizi; Abu Abd ar-Rahman an-Nasa'i; Abu Bakr ibn Abi Dawud; Abu 'Awanah; Abu Sa'id al-A'rabi; Abu Bakr Abdullah bin Muhammad bin Abi ad-Dunya; Abdullah bin Muhammad bin Ya'qub; Abu Ali al-Lu'lu'i; Abu Bakr bin Dassah; and or Abu Salim Muhammad bin Sa'id al-Jaldawi. The Book of Tahdzibul Kamal, Yusuf al-Mishri mentions more than 50 people, both as his teacher and as his students. ${ }^{14}$

Based on the relationship between students and teachers, Abu Dawud had time to learn from Qutaibah bin Sa'id. The narrator of the Hadith which is also a mukharij met with Qutaibah bin Sa'id. Therefore in this first level mukharij with his teacher is muttasil. This figure's full name is Wahb bin Baqiyah bin Uthman bin Sabur bin 'Ubaid bin Adam bin Ziyad al Wasithi. He was born in $155 \mathrm{H}$, and died in $239 \mathrm{H}$, so he is 116 years old. These figures have teachers, which include: Aghlab bin Tamim; Bisyr bin al Mufadhal; Ja'far ibn Sulaiman al Dhuba'i; Hatim bin al Ahnaf al Wasithi; Hakim bin Dhuhair; Hamad bin Zaid Hikayah; Kholid bin Abdullah al Wasithi; and Suht bin Ibrahim al Wasithi; and or Sulaim bin Ahdhor.

The students are Imam Muslim; Imam Abu Dawud; Ibrahim bin Ayub; al-Wasithi al'Adl; Abu al Walid Ahmad bin Bisyr at-Thiyalusy; Ahmad bin Hasan al-Wasithi; Abu Bakr Ahmad bin Ali ibn Sa'id al-Qadhi al-Marwazi; Abu Ya'la Ahmad bin Ali bi al-Mutsana alMaushali; Abu Bakr Ahmad ibn Amru bin Abi 'Ashim; Aslam bin Sahl al-Wasithi Bahtsal;

\footnotetext{
${ }^{13}$ Muhammad Muhammad Abu Syuhbah. Kitab Hadis Sahih yang Enam (Jakarta: Pustaka Lentera Antar Nusa, 1991), pp. 81-82.

${ }^{14}$ See: Jamaluddin Abu al-Hajjaj Yusuf al-Mizri, Tahdzib al Kamal fi Asmaa-i ar Rijal vol. 11 (Beirut: Mu'asassah ar Risalah), pp. 255-261.
} 
Abdullah ibn Ahmad bin Hambal; Abu al-Qashim Abdullah bin Muhammad bin Abdul Aziz al Baghwi; Muhammad bin Ishaq ats-Tsaqawi; and Abdullah bin Musa bin Abi Uthman alBazzaz. ${ }^{15}$

Seeing the data above, related to the Hadith discussed here, Wahb bin Baqiyah was a narrator who met his teacher, Kholid bin Abdullah al-Wasithi, and so he met his student named Imam Abu Dawud. Because the transmission at the first and second levels is continuous or muttasil. The full name of Kholid is Kholid bin Abdullah bin Abdurrahman bin Yazid at Thahan Abu al Haitsam. This figure was born in $110 \mathrm{H}$, and died in $182 \mathrm{H}$, so that Kholid is 72 years old. But according to Abdul Hamid bin Bayan and Ya'qub bin Sufyan that Kholid died in $179 \mathrm{H}$, so he was 69 years old. ${ }^{16}$

These figures have historically had several teachers, among them Ismail bin Hamad bin Abi Sulaiman; Ismail bin Abi Kholid; Abi Bisyr Ja'far bin Abi Wahsyiyah; al Hasan bin Ubaidillah an-Nakhoi; Abi Maslamah Sa'id bin Yazid; 'Ashim bin Kulaib; Abdurohman bin Ishaq al-Madani; Suhail bin Abi Sholih; Abi Ishaq as-Syaibani; and or Abi Hayyan atTaimiy.

As for his students are, among others, Ibrahim ibn Musa ar Razi; Ishaq bin Syaahin alWasithi; Abu Umar Hafsh bin Umar al-Haudhi; Rifa'ah bin al-Haitsim al-Wasithi; Abdurahman bin Mahdi; Sa'id bin Sulaiman al-Wasithi; Qutaibah bin Sa'id; his son, Muhammad bin Kholid bin Abdullah al-Wasithi; Muhammad bin Salam al-Bikandiy; Muhammad bin Muqaatil al-Mawarzi; Wahb bin Baqiyah al-Wasithi; Muhammad bin Shobbah ad-Daulabiy al-Bazzaz; and or Yahya bin Sa'id al-Qaththan.

According to Muhammad bin Sa'id, Abu Zur'ah, Abu Hatim and Tirmidhi, and Nasai that this figure is a person who is tsiqah. Abu Hatim added that Kholid was a true preacher (saheeh), then Turmidzi also added that Kholid was a hafidz (memorized the Quran). This figure in the narration of the Hadith about the people disunity into 73 groups met with his student named Wahb bin Baqiyah, but Kholid was not found to meet with his teacher named Muhammad bin Amru. ${ }^{17}$ Therefore this transmission at the $3^{\text {rd }}$ level, there are sanad who do not meet, so at this level it can be called ghoiru muttasil.

His full name is Muhammad bin Amru bin Alqamah bin Waqas al-Laitsi Abu Abdillah, and is often said to be al-Hasan al-Madani. Muhammad bin Amru died in $144 \mathrm{H}$, while the year of his birth is unknown. It was only said by Sa'id bin Amir that he had come to Basrah in $37 \mathrm{H}$. The code that was included in this figure in the book Tahdzibul Kamal was (ع). With the code $(\varepsilon)$, then this figure is a rijal from the priest of the Kutubus Sittah, which means entered in the rijal of Imam Abu Dawud.

This figure has several teachers, including Ibrahim or Abi Salamah bin Abdurrahman bin Awf; his father, Amru bin Alqamah bin Waqas; Ubaidah ibn Sufyan; Sa'id bin Harith alAnshori; Salim bin Abdullah bin Umar; Ibrahim bin Abdillah bin Hunain; Dinar Abi Abdillah al-Qaradz; Umar bin Muslim bin Akimah al-Laits; Muhammad ibn Ibrahim ibn al-

${ }^{15}$ Jamaluddin Abu al-Hajjaj Yusuf al-Mizri, Tahdzib al Kamal fi Asmaa-i ar Rijal vol. 31, (Beirut: Muasassah ar Risalah), pp. 115-116.

${ }^{16}$ Jamaluddin Abu al-Hajjaj Yusuf al-Mizri, vol. 8, p. 103.

${ }^{17}$ Jamaluddin Abu al-Hajjaj Yusuf al-Mizri, vol. 8, pp. 100-101. 
Harith at-Taimi; Salman Abi Abdullah al-Aghor; and or Waqid bin Amru bin Sa'ib bin Mu'adz.

As for his students, among others are: Asbat bin Muhammad bin Quraishi; Ismail bin Ja'far; Kholid bin Abdullah al-Wasithi; Abu Usamah bin Usamah; Umar bin Abi Khalifah al-'Abdi; Malik bin Anas; Muhammad ibn Abi Syaibah al-'Absy; Muhammad bin Bisyr al'Abdi; Yazid ibn Harun; Abdullah bin Numair; Abu Alqamah Abdullah ibn Muahmmad alFarwi; Yahya ibn Sa'id al-Qaththan and or Mu'adz bin Mu'adz. ${ }^{18}$

Muhammad bin Amru as a figure included by some scholars of Hadith as a good scholar, as stated by Ishaq bin Hakim, that Muhammad bin Umar is a pious person, no one doubts his memorization in the case of Hadith. The information given by Ibn Tuhman, he heard from Yahya bin Mu'in, that Muhammad bin Amru was a person of tsiqah. According to Imam Nasai, this figure is in the words of laisa bihi ba'sa, although at other times he stated that this figure was a tsiqah. Then Ibn Hiban included this figure in the book of ats-Tsiqat. ${ }^{19}$ In conclusion, that Muhammad bin Amru is a person who is salih, intelligent, smart, strong memorization, so it is a reliable narrator in bringing the Hadith.

The full name of this figure is Abu Salamah bin Abdurrahman bin Auf bin Abdi Auf bin Abdi bin Harith bin Zuhrah bin Kilab bin Murrah bin Ka'ab al-Quraisy az-Zuhri alHafizh. He was born in $20 \mathrm{H}$, and died in $95 \mathrm{H}$, so that he was 75 years old. This figure is often referred to as Isma'il or Ibrahim, as stated in the book of Tahdzib al-Kamal. This figure when referred to by the name Ibrahim, has teachers named Jubair bin Mut'im; Sa'id bin Abi Waqas; Tholhah bin Ubadillah; his father, Abdurohman bin Auf; Umar bin Khathb; Ali ibn Abi Talib; Amru bin 'Ash; Abi Bakrah Nufai bin Harith ats-Thaqafi; and or Amar bin Yasir.

The students include his son, Sa'id bin Ibrahim and Shalih bin Ibrahim; Atho bin Abi Rabah; Muhammad bin Amru bin Alqamah ibn Waqash al-Laits; and Muhammad bin Muslim bin Syihab az-Zuhri. This figure was considered by Ahmad bin Abdullah al-'Ijli to be a tabi'in who is tsiqah. ${ }^{20}$ According to Al-Mizri, that this figure, as mentioned in of Tahdzib al-Kamal, is related to the Hadith which narrated through Abu Dawud, met with his teacher named Abu Hurairah. This figure also met his student named Muhammad bin Amru.

The full name of this figure is Abdurrahman bin Syakhr bin Abdurahman bin Wabishah bin Ma'bad al-Asdi ar-Raqiy, who was born in $598 \mathrm{AD}$ and died $678 \mathrm{AD} / 57 \mathrm{H}$. At the age of 78 years. At the time of ignorance, he was named Abdu Syams, and there are others who think differently. His nickname is Abu Hurairah (this is famous) or Abu Hir, because he has a little cat that he always invites to play with. The Hadith expert has agreed, he is the best friend who narrated the Hadith. Abu Muhammad Ibn Hazm said that, in Musnad Baqiy bin Makhlad there were more than 5,300 Hadith narrated by Abu Hurairah.

There are several factors that cause the number of events obtained by Abu Hurairah, among others; a) be diligent in attending the assemblies of the Prophet saw., b) always

\footnotetext{
${ }^{18}$ Jamaluddin Abu al-Hajjaj Yusuf al-Mizri, Tahdzib al Kamal fi Asmaa-i ar Rijal vol. 26, (Beirut: Muasassah ar Risalah), p. 215.

${ }^{19}$ Jamaluddin Abu al Hajjaj Yusuf al Mizri, Tahdzib al Kamal fi Asmaa-i ar Rijal vol. 26 (Beirut: Muasassah ar Risalah) pp. 216-217.

${ }^{20}$ Jamaluddin Abu al Hajjaj Yusuf al Mizri, Tahdzib al Kamal fi Asmaa-i ar Rijal vol. 2, (Beirut: Muasassah ar Risalah), pp. 134-135.
} 
accompany Rasulullah saw., because he is a resident of Shuffah in the Nabawi Mosque. c) strong memory, because he was one of the friends who got the prayer from the Prophet saw., so that his memorization is strong and never forgot what he heard from the Messenger of Allah, d) many met with senior friends even though the prophet had died. Abu Hurairah died in Medina in $57 \mathrm{H}$. at the age of 78 years and during his life was devoted to the discovery and preservation of the Hadith of the Prophet Muhammad. ${ }^{21}$

In addition to narrating from the Prophet saw., Abu Hurairah also narrated the Hadith from Abu Bakr, Umar, al-Fadl ibn al-Abbas, Ubay bin Ka'ab, Usamah bin Zaid, 'Aisha, Bushrah al-Ghifari, and Ka'ab al-Ahbar r.a. There are about 800 experts from among the companions and the tabi'in who narrated the Hadith from Abu Hurairah, and he is the most memorized person in narrating thousands of Hadiths. However, that does not mean he is the most important among the companions of the Prophet Muhammad.

Imam Shafi'i said, "Abu Hurairah, is the person who is most familiar in narrating the Hadith in his day (the time of the Companions)." Abu Hurairah convert to Islam between after the Hudaibiyyah Agreement and before the Khaibar War. He came to Medina as a migrant who then lived in Shuffah.

Amr bin Ali al-Fallas said, Abu Hurairah, came to Medina in the year of the Khaibar War in Muharram $7^{\text {th }}$ year $\mathrm{H}$. This figure is related to the Hadith of the disunity of Muslims into 73 groups, both in the book of Tahdzib al Kamal by al Mizri, or in the book of Tahdzib al-Tahdzib by Ibn Hajar al-Asqalani it is not known that he and Abi Salamah met. ${ }^{22}$ Therefore, transmission in this stage occurs ghoiru muttasil (not continued). Likewise in the $3^{\text {rd }}$ narrator period of narrator 4 , or the $3^{\text {rd }}$ sanad with the second sanad that is between Kholid and Muhammad bin Amru also could not be met, even though the order of the other sanad was continued.

Observing the existence of the existing sanad in the path of Imam Abu Dawud in the Hadith of the disunity of Muslims into 73 groups, there are two intermittent sanad sequences, then the position of this Hadith has not reached the saheeh degree. Therefore it cannot be used as a proof in justifying Muslims will be disunity into 73 groups.

\section{b. Sanad Path of Imam at Tirmidhi}

The full name of Imam at Tirmidzi is Abu 'Isa Muhammad bin 'Isa bin Saurah bin Musa bin ad-Dahak as-Sulami at-Tarmidzi. At-Tirmidzi was born on the southern side of the Jihun river, Usbekistan, in the city of Tirmidz. The authors do not say exactly when Imam at-Tirmidhi was born. According to Shaykh Muhammad 'Abd Al Hadi Al Sindi Imam at-Tirmidzi was born in $209 \mathrm{H}$. Al-Shalah al-Safadi mentioned that Imam at-Tirmidzi was born in $200 \mathrm{H}$. Then according to some other scholars, he was born in $209 \mathrm{H}$. (824 AD). ${ }^{23}$ He died on the 13 Rajab $279 \mathrm{H}$, at the age of 70 years.

$\mathrm{He}$ is an Islamic scientist, canonical Hadith collector (book standard). Abu Ya'la al-

\footnotetext{
${ }^{21}$ Muhajirin, Ulumul Hadits II (Palembang: Noer Fikri, 2016), pp. 92-93.

${ }^{22}$ See: Syihabudin Abi al-Fadhl Ahmad bin Ali bin Hajar al-Asqalani, Thadzibu at Tahdzib vol. 6 (Kairo: Darl Kitab al Islami), pp. 199-201; Jamaluddin Abu al-Hajjaj Yusuf al-Mizri, Tahdzib al Kamal fi Asmaai ar-Rijal vol. 17 (Beirut: Muasassah ar-Risalah), pp. 184-185.

${ }^{23}$ Depag RI, Ensiklopedi Islam III (Jakarta: Depag RI, 1993), pp. 1246-1248.
} 
Khalili, a Hadith expert stated that at-Tirmidhi was a tsiqah (trusted), and this was agreed upon by the scholars. Ibn Hibban al-Busti (Hadith expert) acknowledged at-Tirmdzi's ability to memorize, collect and compile Hadiths.

At-Tirmidhi was a student of Imam Bukhari and several other teachers such as: Qutaibah bin Sa'id, Ishaq bin Musa. His famous book, Jami 'at-Tirmidzi which collects fiqh issues with detailed explanations. Imam at-Tirmidzi also studied with Imam Muslim and Imam Abu Dawud, even he learned the Hadith from some of their teachers. The teachers include: Ishaq bin Musa; Mahmud bin Gailan; Sa'id bin Abd ar-Rahman; Muhammad bin Basyar; Ali bin Hajar; Ahmad bin Muni '; and or Muhammad bin al-Musanna. At-Tirmidzi as mukharrij in the Hadith. The sanad which is the path is the same as the sanad that has been passed by Imam Abu Dawud, so the narrators are not revealed again, because it has been discussed above.

The full name of this figure is al-Husein bin Huraits bin al-Hasan bin Thabit bin Qutabah al-Huza'i. He died in the year $244 \mathrm{H}$., while the year of his birth was not much revealed by the scholars. Husein bin Huraits has so many teachers, namely: Isma'il bin Ulayah; Aus bin Abdillah bin Buraidah al-Aslami; Sa'id bin Salim al-Qaddah; Abdullah bin al-Mubarak; Abdullah bin Nafi 'bin Thabit az-Zubairi; Ali bin al Hasan bin Syaqiq; 'Isa bin Yunus; al-Fadl ibn Musa as-Sinani; Abi Muawiyah Muhammad bin Khozim ad-Dhorri; Muawiyah bin Amru al-Azdi; and or Nashr ibn Kholid.

The students include Ibrahim bin Muhammad bin al-Hasan bin Matwiyah alAshbahani; Ahmad bin Musa al-Jauhari; al-Baghdadi; Ishaq ibn Ibrahim bi Ismail al-Bustiyu al-Qaadhi; Abdullah bin Ahmad bin Hambal; Abdullah bin Muhammad bin Abi Dunya; Abdullah bin Muhammad al-Baghawi; Muhammad bin Abdullah bin Sulaiman al-Hadrami; Abu Ahmad Muhammad ibn Abdul Wahab ibn Hubaib al-Farai; Muhammad bin Ali alHakim at-Tirmidzi; Muhammad bin Harun al-Hadromi; and or Yahya bin Muhammad bin Sho'id. ${ }^{24}$

This figure in the book of Tahdzib al-Kamal was stated to meet with his teacher named al-Fadhl ibn Musa, but he did not meet his student named imam at-Tirmidhi. Muhammad bin Ali al Hakim at-Tirmidhi is not a Hadith expert, but an Islamic thinker who is a creative and prominent. He was expelled from his hometown, then Tirmidzi fled to Nishapur where he gave lectures in $285 \mathrm{H} / 898 \mathrm{AD}$. His psychological works greatly influenced al-Ghazali, while his extraordinary and horrendous theory was about the Holy Man taken and developed by Ibn Arabi. ${ }^{25}$ Thus the last narrator or the sixth narrator on the Hadith of the disunity of the people into 73 groups, namely the priest Tirmidzi did not meet with his teacher named Husein bin Huraits Abu Amar. Therefore in the order of sanad in this thabaqat is ghoiru muttasil.

This figure's full name is al-Fadl ibn Musa as-Sinani Abu Abdillah al-Marwazi. He was born in $115 \mathrm{H}$, and died in $192 \mathrm{H}$, so he is around 77 years old. The code that is included

\footnotetext{
${ }^{24}$ Jamaluddin Abu al-Hajjaj Yusuf al-Mizri, Tahdzib al-Kamal fi Asmaai ar-Rijal vol. 6 (Beirut: Muasassah ar-Risalah), p. 360.

${ }^{25}$ Biography Abu Abdullah Muhammad bin 'Ali bin al Husein al Hakim at Tirmidzi ra. https://www. konfrontasi.com/content/khazanah/riwayat-hidup-abu-abdullah-muhammad-bin-\%E2\%80\%99 ali-bin-alhusain-al-hakim-tirmidzi-ra, accessed, April 9, 2020.
} 
on this character in the book Tahdzbul Kamal is $(\varepsilon)$. With the code $(\varepsilon)$, then this figure is a rijal from the priest of the Kutubus Sittah, which means entered in the rijal Imam atTirmidzi.

Al-Fadhl has several teachers, among others: Ismail bin Abi Kholid; al-Husein bin Dzakwan al-Mu'allim; Khutsaim bin 'Irak bin Malik; Sufyan ats-Tsauri; Salamah bin Wardan; Sulaian al-'Amasy; Shalih bin Abi Jubair; Abdullah bin Sa'id bin Abi Hind; Abdul Hamid bin Ja'far al-Anshori; Uthman bin al-Aswad; Isa bin 'Ubaid al-Kindi; Muhammad bin Amru bin Alqamah; Abi Hamzah Muhammad bin Maimun as-Sukari; Ma'mar bin Rasyid; Abi Hanifah an-Nu'man ibn Thabit; Yazid bin Thahman; and or Yunus bin Abi Ishaq.

The students include Abu Ishaq Ibrahim bin Ishaq at-Tholiqani; Ibrahim bin Abdullah bin Hatim al-Harawi; Bisyr bin Hakim an-Naisaburi; Hamid bin Adam al-Marwazi; Abu 'Amar al-Husein bin Huraits; al-Husein bin ad-Dhahak; Sa'id bin Sulaiman al-Wasithi; and or Muhammad bin Humaid ar-Razi. According to Abu Bakr bin Abi Khoitsamah that alFadhl was a narrator who was tsiqah. The same was stated by Muhammad bin Sa'id. As according to Abu Hatim, al-Fadhl is a person who: صدا لح and صدا. Then Ibn Hibban included this figure in the book of Tsiqah. ${ }^{26}$

Seeing the data above, this figure met with his teacher Muhammad bin Amru bin Alqamah, or with his student named Husein bin Huraits. Therefore, in this thabaqat they meet, so that this thobaqat is mututasil. In the next tahabaqat, the narrator named Muhammad bin Amru bin Alqamah, Abi Salamah and Abu Hurairah on the Tirmidzi route is not explained, because it has been explained in discussing sanad on the path of Imam Abu Dawud.

Illat in this path is on the two thabaqat, namely the narrator at Tirmidzi himself, because he did not meet with his teacher named al-Fadhl ibn Musa as-Sinani, and secondly on the $4^{\text {th }}$ and $5^{\text {th }}$ sanad, namely Abi Salamah with Abu Hurairah not met, so that this Hadith through the path of Imam Tirmidzi there is a weakness namely sanad ghoiru muttasil.

\section{c. Sanad Path of Ibnu Majah}

The full name of this figure is Abu Abdullah Muhammad bin Yazid Ar-Rabi 'bin Majah Al-Qazwinî Al-Hafidz, but he is usually called Ibn Majah. The name Majah is attributed to his father Yazid, also known as Majah Maula Rab'at. This figure was born in $209 \mathrm{H}$, while his death was in $273 \mathrm{H}$. In the course of his scientific context it turned out that many expert sheikhs were met by the imam in the field of Hadith; among them are: the two children of Shaykh Shaybah (Abdullah and Usman), but the Imam narrated more of the Hadith from Abdullah bin Abi Syaibah. And also Abu Khaitsamah Zahir bin Harb, Duhem, Abu Mus'ab Az-Zahry, Al-Hafidz Ali ibn Muhammad At-Tanafasy, Jubrah bin Mughallis, Muhammad bin Abdullah bin Numayr, Hisham bin Ammar, Ahmad bin al-Azhar, Basyar bin Muhammad Adam and his followers of narrators and Hadith experts Imam Malik and al-Layts.

${ }^{26}$ Jamaluddin Abu al-Hajjaj Yusuf al-Mizri, Tahdzib al-Kamal fi Asmaai ar-Rijal vol. 23 (Beirut: Muasassah ar-Risalah), pp. 254-258. 
Among his students who studied with him were: Abu al-Hasan Ali ibn Ibrahim alQatthan, Sulaiman bin Yazid, Abu Ja'far Muhammad ibn Isa Al-Mathu'î and Abu Bakar Hamid Al-Abhary. These four students are the narrators of Sunan Ibn Majah, but what reaches us now is from Abu Hasan bin Qatthân alone. ${ }^{27}$

The book written by Imam Ibn Majah is in the form of Sunan, a term used for a book of Hadith which in it is still mixed with the authentic Hadith and the Hadith which has a degree of dho'if (weak). But the book of Sunan Ibn Majah by al-Hafiz Abul-Fardl Muhammad bin Tahir al-Maqdisi (died 507 AH) in his book Atraful Kutubus Sittah and in his treatise Syurutul 'A 'immatis Sittah, is included as the book of sittah (the sixth book). This opinion was then followed by al-Hafiz 'Abdul Gani bin al-Wahid al-Maqdisi (died $600 \mathrm{H}$ ) in his book Al-Ikmal fi Asma' ar-Rijal. ${ }^{28}$ Furthermore, their opinion was followed by most of the later scholars.

The full name of this figure is Abdullah bin Muhammad bin Ibrahim bin Uthman bin Khawasiti al 'Absiy. He is better known as Abu Bakr bin bin Abi Shafi'ah. This figure is also known as a reliable hafidh. He died in $235 \mathrm{H}$, while the year of his birth was not widely known. Abu Bakr has teachers, which include: Ahmad bin Ishaq al Hadrami; Ahmad bin Abdullah ibn Yunus; Ishaq bin Sulaiman ar Razi; Isma'il bin 'Ayasy; Ja'far bin 'Aun; Hatim bin Ismail al Madani; Dawud bin Abdullah bin Abi al Kirom al Ja'fari; Zaid bin al Hubab; Suwaid bin Amru al Kalbi; Abdullah bin Idris; Abdullah bin Bakr as Sahmi; Abdullah bin al Mubarak; Abdullah bin Numair; Abdurahman bin Mahdi; Abdul Wahab bin Ubaid as Tsaqafi; Qutaibah bin Sa'id; Muhammad bin Bisyr al 'Abdi; Muhammad bin al Hasan bin az Zubair al Asdi; Muhammad bin Sabiq; Muhammad bin Abi Ubaidah; Marwan bin Mu'awiyah; al Fazzari; Mu'alla bin Mansur ar Razi; Yahya bin 'Isa al Ramli; Yazid bin al Miqdam bin Syuraih bin Hani; and or Yunus bin Muhammad bin al-Muaddib.

As for his students, among others: al Bukhori, Muslim; Abu Dawud, Ibn Majah; Ibrahim bin Ishaq al Harbi; Ahmad bin Muhammad bin Hambal; Ahmad bin Yahya bin Jabir al Baladzuri; Ishaq bin al Kholil al Baghdadi; Abu Ya'qub Ishaq bin Abi Imron and is often referred to by the name Musa bin 'Imron an Naisaburi; al Hasan bin Sufyan as Syaibani; Abu Hamid Hamdan bin Gharim al Bukhori; Abdullah bin Ahmad bin Hambal; Muhammad bn Ibrahim Murabba '; Muhammad bin Ubaidillah ibn al Munadi; and or Abu Amru Yusuf bin Ya'qub an Naisaburi. ${ }^{29}$

According to al 'Ijli, Abu Hatim and Ibn Khirasy that this figure is a person who is tsiqah. Even al 'Ijli added that he was a person who memorized many Hadiths. ${ }^{30}$ This figure in the order of transmission which includes from the mukharij al Hadith to the second stage is continued or muttasil, because Abu Bakr met with Ibn Majah. His full name is Muhammad bin Bisyr bin al Farashah bin al Muhtar al Hafidz al 'Abdi Abu Abdillah al Kufi. According to Imam Bukhori and Ibn Hiban, this figure died in $203 \mathrm{H}$. The code that is included on this figure in the book Tahdzbul Kamal is $(\varepsilon)$. With the code $(\varepsilon)$, then this figure as a rijal from

\footnotetext{
${ }^{27}$ Biography of Imam Ibnu Majah, http://bukuensiklopediahadits/2013/04/biografi-imam-ibnumajah.html, Accessed Feb. 16, 2018.

${ }^{28}$ Jamaluddin Abu al-Hajjaj Yusuf al-Mizri, vol. 23, pp. 254-258.

${ }^{29}$ Jamaluddin Abu al-Hajjaj Yusuf al-Mizri, Tahdzib al Kamal fi Asmaai ar-Rijal vol.16, (Beirut: Muasassah ar Risalah), pp. 35-39.

${ }^{30}$ Jamaluddin Abu al-Hajjaj Yusuf al-Mizri, vol. 16, p. 41.
} 
the priest of the Kutubus Sittah, which means entered in the rijal of Imam Ibn Majah.

This figure has several teachers, including Ismail bin Abi Kholid; Hisham bin Abi Urwah; Ubaidillah bin 'Amr; Hajaj bin Abi Uthman as Shawaf; Sufyan ats Tsauri; Sulaiman al 'Amasy; Syu'bah bin al Hajaj; Yazid bin Ziyad bn Abi al Ja'di; Abdul Aziz ibn 'Amr bin Abdul Aziz; Amru bin Maimun bin Mihran; Muhammad bin Amru bin Al Qamah; Nafi 'bin Umar al Jumahi; and or Hani ibn Uthman al Juhani.

Then this figure also has several students, among them are: Ahmad bin Sulaiman ar Rohawi; Abu Mas'ud Ahmad bin al Furat ar Razi; Ahmad bin Yahya as Shufi; Abu Bakr bin Abi Syaibah; Muhammad bin Abdullah bin Numair; Musa bin Hizam at Tirmidhi; Musa bin Abdurrahman al Masruqi; Ubadah bin Abdullah as Shofar; and or Harun bin Abdullah bin al Hambal. According to the assessment of al-Nasa-i, Ibn Nafi 'and Uthman bin Abi Syaibah that Muhammad ibn Bisyr was a tsiqah. ${ }^{31}$

This figure in the book of Tahdzib al Kamal found a relationship between teacher and student, namely between Muhammad bin Bisyr with Abu Bakr bin Abi Syaibah. This mean that they met, so that the Hadith about the disunity of the people into 73 groups in the fourth sequence of transmission is connected or muttasil. The next narrator is Muhammad bin Amru as the third narrator, then Abi Salamah as the second narrator and Abu Hurairah as the first narrator has been revealed in the Sanad study of Imam Abu Dawud's route, then the Imam Ibn Majah's line is not explained again. Illat in this path is only found in the 2nd narrator with the 1st narrator, ie they did not meet, so this Hadith has a weakness. Therefore it would be wise not to be used as evidence in applying a law.

\section{d. Sanad Path of Imam Ahmad bin Hambal}

His full name is Abu Abdillah bin Muhammad bin Hambal al-Marwazy. He is a famous Hadith scholar born in Baghdad. He was born in the month of Rabiul Awal, $164 \mathrm{H} /$ $780 \mathrm{AD}$, and died in $241 \mathrm{H}$. He is famous as one of the founders of the madzhab as Hanabilah (Hambaly). He began searching for Hadiths since he was 16 years old to migrate to cities in the Middle East. From this overseas, he got famous teachers, including: Sufyan bin 'Uyainah, Ibrahim bin Sa'd, Yahya bin Qaththan. He is one of the most loyal students of Imam asy-Syafii.

He is a Hadith expert who is recognized for his simplicity. According to Abu Zur'ah, he has 12 kinds of writing which are mastered. He also has memorized matan Hadith as many as 1,000,000 pieces. His most famous work is Musnad al-Kabir. This book contains 40,000 pieces of Hadith, and 10,000 of its which were Hadiths he had written. His most important work is Musnad Ahmad which is composed of 30,000 Hadith in 24 juz.

He began studying Hadith in $178 \mathrm{H}$, when he was 16 years old and memorized thousands of Hadiths during his lifetime. This figure carried out his studies, mostly in the city of Baghdad, however he also traveled to various places, and his initial steps were to study Qadhi Abu Yusuf (d. 189 H) and then study the Hadith of Imam Abu Hanifah. Finally he became a student of Imam al-Shafi'i to study fiqh and Hadith.

${ }^{31}$ Syihabudin Abi al-Fadhl Ahmad bin Ali bin Hajar al-Asqalani, Thadzibu at-Tahdzib vol. 9 (Kairo: Darl Kitab al-Islami), p. 74. 
When he went to Yemen Imam Ahmad studied with Abd al-Razzaq, and after that traveled to learn the Hadith of Bisyr al-Mufadhdhal al-Raqqasyi, Sufyan ibn 'Uyainah, Yahya ibn Said al-Qaththan, Abd Razzaq ibn Hamman al-Shan'ani, Sulaiman ibn Dawud alThayalla, Ismail ibn Ulayah, Mu'tamir ibn Sulaiman al-Bashri. ${ }^{32}$

Concerning his personal glory, Ibn Hibban stated that he was a figh expert, a strong hafidz, always in a 'wara' manner, and faithful in worship. Allah preserved it from heresy, and even Imam Shafi'i stated that in terms of establishing the validity and innocence of the Hadith, Imam Shafi'i still relied on Imam Ahmad, and further he stated I was out of Iraq and I did not leave anyone more main, more wara', and more godly to him apart from Ahmad ibn Hambal. ${ }^{33}$ The next sanad were Muhammad bin Bisyr, Muhammad bin Amru, Abi Salamah and Abu Hurairah. These narrators have been explained in the line of Imam Abu Dawud's sanad and also in the line of Imam at Tirmidzi, then in the line of Imam Ahmad bin Hambal no longer explained.

\section{Review of the Hadith about Disunity of the Ummah}

\section{The Quran View}

Humans come from one creature, Adam. In its development into thousands of tribes and qabilah scattered throughout the world. They live in different colors of skin, culture, social, language, ethnicity, nationality, creed, ideology, and/or religion. Therefore a difference is something natural. Qv. Al-Hujurat/49: 13, states:

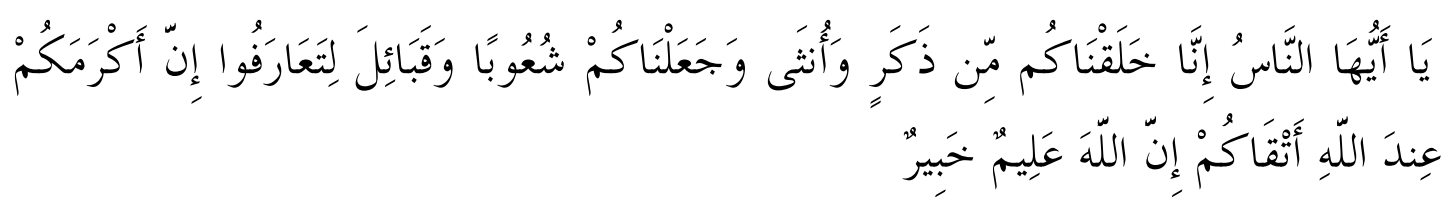

Human beings, We created you all from a male and a female, and made you into nations and tribes so that you may know one another. Verily the noblest of you in the sight of Allah is The Most God-fearing of you. Indeed, Allah is All-Knowing, AllAware.

Ethnic and other differences according to the Quran are not a barrier to interacting with one another. Because the Quran itself commands to ta'aruf (know each other). Ta'aruf should be interpreted not merely to know the physical only, but it would be better if you also know about the ideology, the character of his tribe, his beliefs, his religion, and/or worship behavior. This recognition that is not merely physical will lead to the next character, which is to be a tolerant, moderate, and inclusive person. Such personalities will be able to avoid being exclusive, radical, violent or fanatical, so that they are not easily trapped in the recognition of group truth claims.

Regarding fanaticism of groups, the Quran has banned it, as a preventive effort from the emergence of disunity in religion, as stated in qv. Rum/30: 31-32.

\footnotetext{
${ }^{32}$ Nawir Yuslem, Sembilan Kitab Induk Hadis, Biografi Penulisnya dan Sistematika Penulisannya (Jakarta: Hijri Pustaka Utama, 2006), p. 36.

${ }^{33}$ Nawir Yuslem, p.37
} 

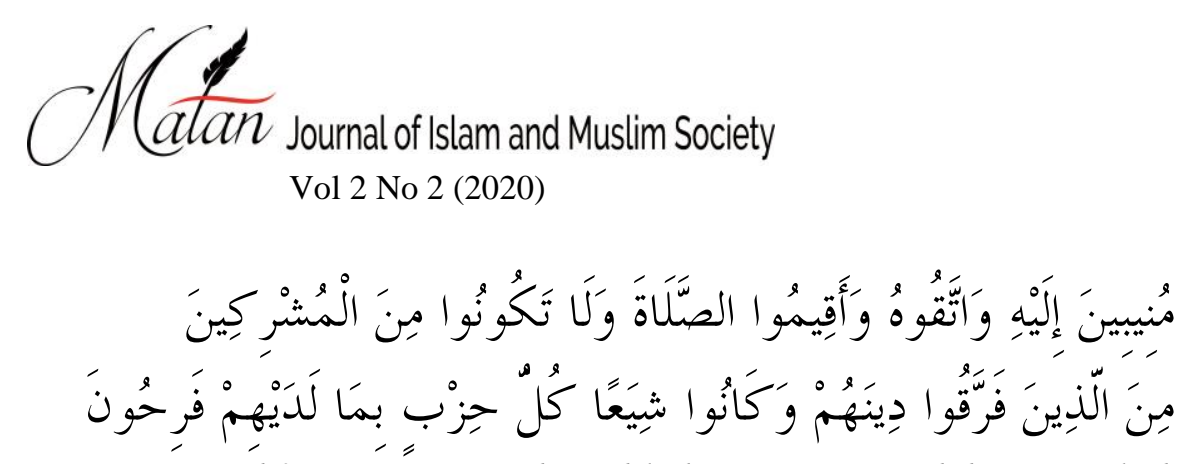

By repenting to Him again and fearing Him and establishing prayer and do not include those who associate partners with Allah (31), (namely) those who divide their religion and they become several groups. Each group feels proud of what is in their group.

When referring to these verses, actually the prohibition of Allah is very strict, that is, if someone falls into a group fanaticism, then he can fall in "polytheism", a punishment which in the assessment of Islamic aqeeda is very heavy. Because someone who is in the category of "polytheists" can result in the fall of the good deeds that have been etched in his life (qv. az-Zumar/39: 65 and qv. al-Anam/6: 88).

Therefore the Quran guides the people to remain united in Islam. Muslims should not be divided into groups that are suspicious of each other, hate each other, are abusive, fanatical, radical, violent, and claim to be the most correct. Even though in the social life of Muslims there are so many groups, because this is a reality, then these groups should mutually ta'aruf in a broader meaning, so that they know each other's "personalities". Attitudes like this will be easier to appear as someone who is more tolerant, moderate and open, compared to groups that are always closed, exclusive, and do not want to ta'aruf with other groups.

Moreover, Muslims are ordered to maintain unity such stated by qv. Ali Imran/3: 103.

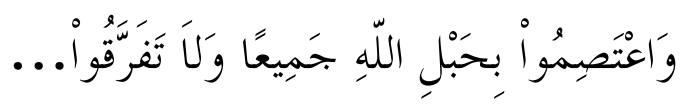

And hold all of you to the string (religion) of Allah, and do not be divorced..."

\section{The Hadith View}

The scholars agree that the functions of the Hadith is to explain and strengthen the laws in the Quran, explains the meaning of the Quran through, explains the meaning that is still vague or general, detailing verses that are global. The last explanation has example as determining prayer times. The other functions of Hadith is limiting the meaning of general verses, such as inheritance rights between men and women. Hadith can expand the purpose of verse, such as the prohibition of the Quran against a man combining two sisters, is extended, including a ban on his mother's siblings. The other function is to establish new laws, which are not clearly stated in the Quran. This is what the term itsbat. ${ }^{34}$

The Hadith about the division of Muslims into 73 groups that are being researched by this study, its nature is still common, because it only tells that Muslims will be divided into 73 groups, there is no takhsis (specialization), which groups are right and then survived. Therefore, the following Hadiths are presented relating to the division of the Muslim community in which the group which has been explained, namely:

\footnotetext{
${ }^{34}$ Tasbih, 'Kedudukan dan Fungsi Hadis Sebagai Sumber Hukum Islam,' Jurnal Al-Fikr 14.1 (2010),
} p. 336. 


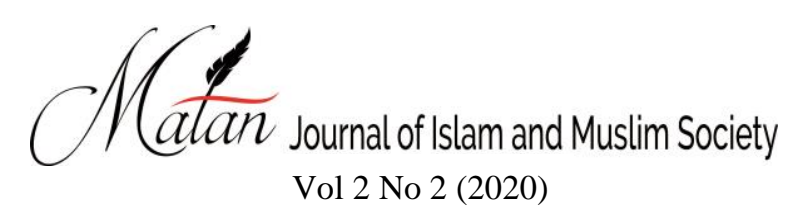

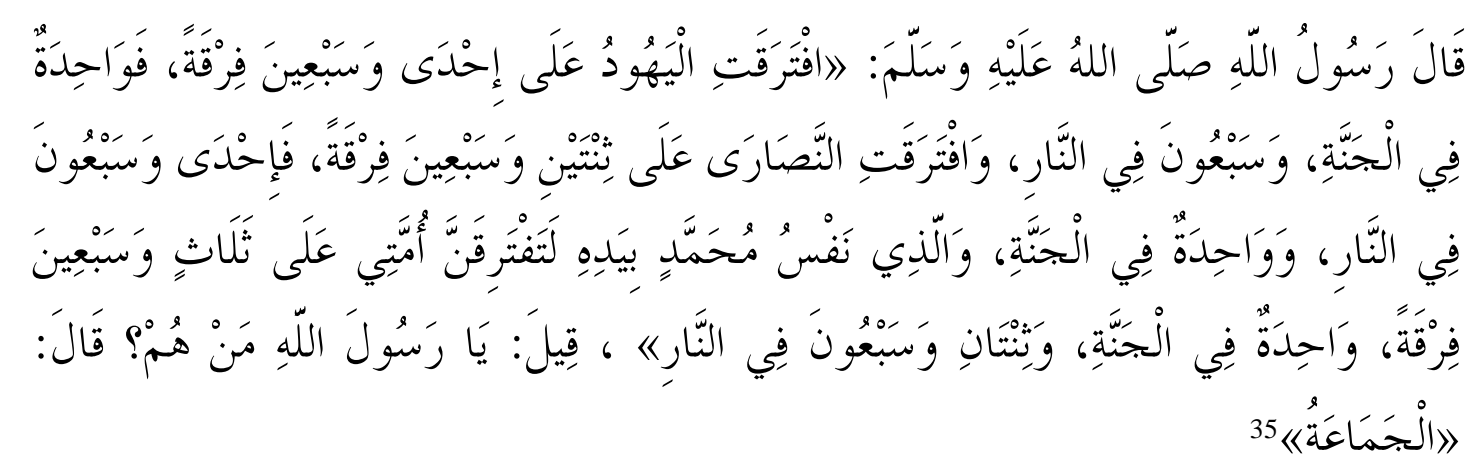

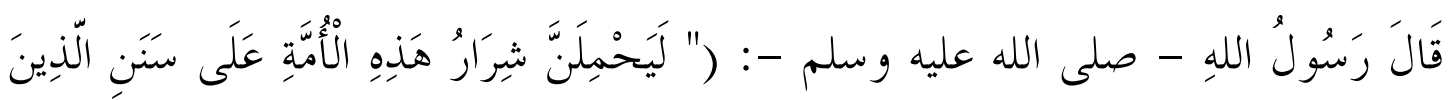

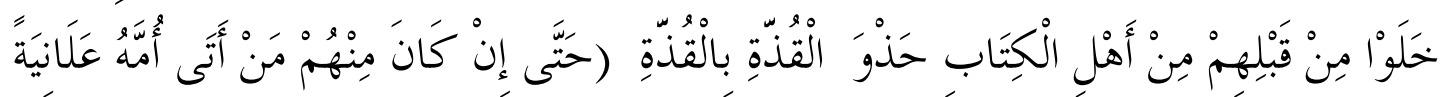

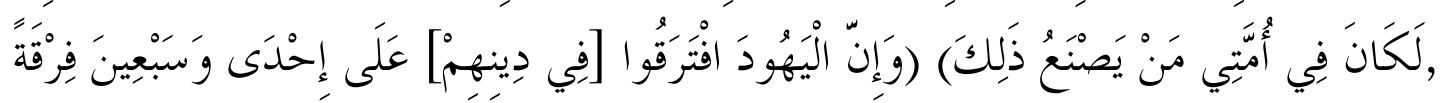

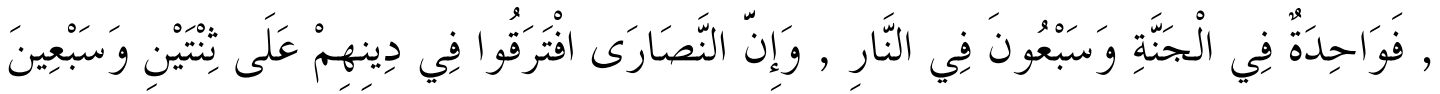

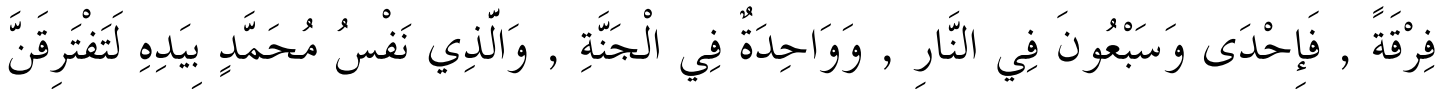

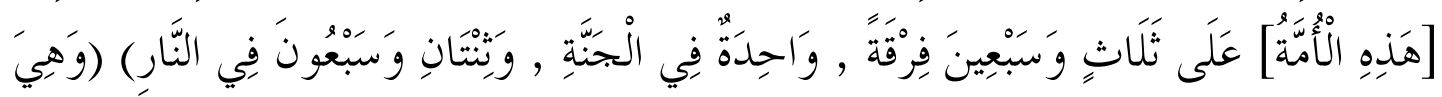

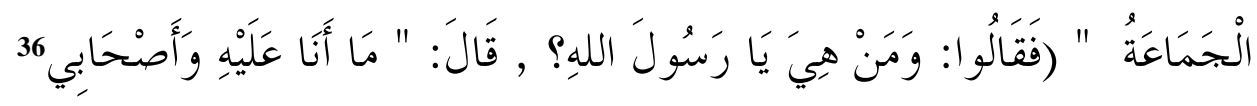

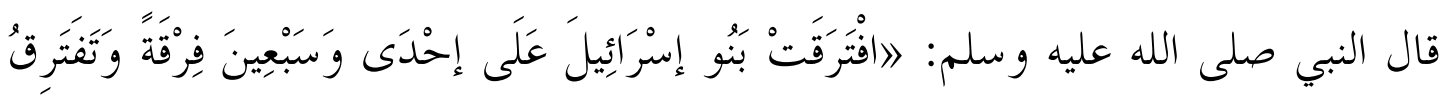

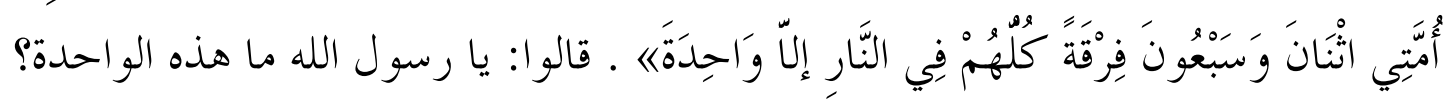

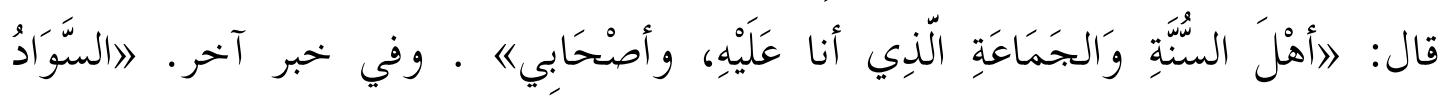

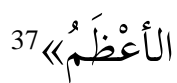

According to the Hadiths, that Muslims will be divided into 73 groups, and there is one group that will survive, then get heaven. They are al-jama'ah, the group who follow the Prophet and his companions, and the largest group or as-suwad al-'adzam. The three groups are takhsis of 72 groups, and basically lead to one understanding, namely a group of people who are above the sunnah of the prophet and atsar companions. The Messenger of Allah gave a statement to follow atsar companions, of course, because they always carry out the sunnah of the Prophet and his behavior and character did not deviate from his instructions.

These terms in its development became the term ahlus sunnah wal jama'ah, which,

${ }^{35} \mathrm{Abu}$ Abdillah Muhammad bin Yazid bin Abdullah bin Majah al-Qazwaini, As-Sunan vol. 5 (Damaskus: Dar ar Rislaah al-'Alamiyah, 2009), pp.128-129.

${ }^{36} \mathrm{Abi}$ 'Isa Muhammad bin 'Isa bin Saurah At Tirmidzi, Jami'u at Tirmidzi (Saudi Arabia: Bait al Afkari ad Dauiliyat, t.t.), p. 428.

${ }^{37}$ Abi al-Laits Nashr bin Muhammad bin Ahmad bin Ibrahim as-Samarqandy, Tafsir al Samarqand vol. 1 (Beirut: Dar al Kutub al-'Ilmiyah, 1993), p. 492. 
according to Ibn Taymiyyah, was meant as a person who followed the sunnah, not a bid'ah, who survived from a doubt about aqeeda. ${ }^{38}$ In another sense, ahlus sunnah wal jama'ah is holding fast to the prophet Muhammad saw. and his companions, and in terms of amaliyah are all activities that have the basis of the Quran and Hadith, both implicitly and explicitly, as well as guarding from an engineering commonly called bid'ah. ${ }^{39}$

Therefore the main shot is to maintain the appearance of disputes, friction, disharmony, conflict among the people. This is because the Messenger of Allah, his attitude, behavior, words and ideals always lead to peace, coolness, tolerance (tasamuh), equality, and justice. If they claim to be the group of ahlul jama'ah, ahlus sunnah wal jamaah and or as suwad al-'adzam, but if their behavior, attitudes and fatwas conveyed actually lead to disputes and/or conflicts, then it should not claim to be the group. Because it is not in line with what is desired by the Prophet Muhammad.

\section{Considerations of Ushul Fiqh}

The ulama ushul said that the purpose of the shari'a is imposed on humans is inseparable from the effort to apply ahkamul khamsah, the application of the five laws, to realize the benefit of humans. Those are to guard din (religion), nafs (soul), nasl (descendants), mal (property), and aql (reason). ${ }^{40}$

Submission of a Hadith to humanity is a realization of Islamic teachings. The goal is that people can know, understand and be able to carry out what is stated in the Hadith correctly. However, if the delivery of a Hadith to hate a group and has an interest in power, so the purpose of the delivery of the Hadith is out of the principle of ahkamul khamsah, especially maintaining of $\operatorname{din}$ (religion), so that not seldom the delivery of a Hadith actually results an altercation and conflict among the people.

A dictum of ushul fiqh: dar'ul mafasir muqadimu 'ala jalbil mashalih (refusing the damage is more important than reaching the benefit. ${ }^{41}$ Submission of a Hadith is a benefit. However, if the delivery (its might aim for the power interest), will bring to harm, so it would be better if the delivery of the Hadith is precisely controlled. The priority is religious interest, which is unity. Perhaps an interest has been achieved, but if it destroys the unity of the people, so it should be abandoned, because it will bring disaster to the existence of religion itself.

\section{E. Conclusion}

Based on the description of the search for sanad and the narrators of the Hadith as well as a review of the analysis of the Quran, Hadith, and ushul fiqh, it can be concluded that difference is a necessity, but disunity is not a natural thing so it needs to be prevented and avoided. The Hadith regarding "Disunity of the ummah into 73 groups" includes the famous

\footnotetext{
${ }^{38} \mathrm{Abu}$ Muhammad Waskito, Mendamaikan Ahlus Sunnah di Nusantara, Mencari Titik Kesepakatan antara Asy'ariyah dan Wahabiyah (Jakarta: Pustaka al Kausar, 2012), p.27.

${ }^{39}$ Muhammad Machfudz, 'Konsep Ahlus Sunnah, Tahqiq dan Dirasah Kitab Hujjah Ahl As-Sunnah wa al Jama’ah Karangan K.H. Ali Maksum, Tesis, Pascasarjana UIN Yogyakarta, 2010, p. 23.

${ }^{40}$ La Jamma, 'Dimensi Ilahi dan Dimensi Insani dalam Maqashid al-Syari'ah,' Asy-Syir'ah Jurnal Ilmu Syari'ah dan Hukum, 45.2 (2011), p. 1257.

${ }^{41}$ Asjmuni A. Rahman, Qaidah-Qaidah Fiqh (Jakarta: Bulan Bintang, 1976), p. 75.
} 
Hadith (popular), and has been widely conveyed by many figures and even the general public has also known the Hadith. The narrators on each path or sanad traversed by the mukharij, on thobaqat tabi'in namely Abi Salamah with a shahabat named Abu Hurairah unknown meeting. Although in terms of years, they are likely to meet. Because Abi Salamah lived in 20-95 H, while Abu Hurairah died in $57 \mathrm{H}$. But because it was clearly unknown, let alone every narrator's line, there was not continued (ghoiru muttasil), so the position of this Hadith did not reach the degrees of saheeh.

Based on a review of the analysis of Quran, Hadith, or ushul fiqh, then the Hadith about the disunity of Muslims into 73 groups, it is better not to be used as the main ingredient in lectures and or sermons, because it brings more damage than the benefit. Thus the study of the takhrij al-hadith about the disunity of the ummah into 73 groups.

\section{References}

Abdullah, Anzar, 'Radikalisme dalam Islam: Perspektif Historis,' Addin, 10.1 (2016), 128.

Akib, Nasri, 'Kesahihan Sanad dan Matan Hadis: Kajian Ilmu Ilmu Sosial', Shautut Tarbiyah, 15.1 (2009), 102-119.

Al-Asqalani, Syihabudin Abi al Fadhl Ahmad bin Ali bin Hajar,Thadzibu at Tahdzib, vol. 6 (Kairo: Darl Kitab al Islami).

Al-Mizri, Jamaluddin Abu al Hajjaj Yusuf, Tahdzib al Kamal fi Asmaa-i ar Rijal, vol. 2, 6, 8, 9, 11, 16, 17, 23, 26, 31 (Beirut: Muasassah ar Risalah).

As-Samarqandy Abi al-Laits Nashr bin Muhammad bin Ahmad bin Ibrahim, Tafsir al Samarqand (Beirut: Dar al Kutub al 'Ilmiyah, 1993).

As-Sijistaniy, Abi Dawud as-Sulaiman bin al-Asy'atsi, Sunan Abi Dawud (Saudi Arabia: Bait al Afkari ad-Dauiliyat, t.t.).

At Tirmidzi, Abi 'Isa Muhammad bin 'Isa bin Saurah, Jami'u at Tirmidzi (Saudi Arabia: Bait al Afkari ad Dauiliyat, t.t.).

Atabik, Ahmad, 'Melacak Historis Syi' ah: Asal Usul Perkembangan dan Aliran-Alrannya', Fikrah: Jurnal Ilmu Aqidah dan Studi Keagamaan, 3.2 (2015).

Biography Abu Abdullah Muhammad bin 'Ali bin al Husein al Hakim at Tirmidzi ra. See: https://www. konfrontasi.com/content/khazanah/riwayat-hidup-abu-abdullahmuhammad-bin-\%E2\%80\%99ali-bin-al-husain-al-hakim-tirmidzi-ra, [accessed, April 9, 2020].

Biography of Iamm Ibnu Majah, See :http://bukuensiklopediaHadith/2013/04/biografiimam-ibnu-majah.html, [Accessed Feb. 16, 2018].

Depag RI, Ensiklopedi Islam III (Jakarta : Depag RI, 1993).

Fianto, Jefri Adi, 'Representasi Peristiwa Kerusuhan Sunni Syiah di Sampang Madura dalam Foto Foto Di Majalah Tempo, Edisi 24 Agusutus 2012-11 Agustus 2013 in Commonline Departemen Komunikasi, 4.1.

Gaffar, Abdul, 'Jamaah Ahmadiyah Indonesia (JAI) dalam Perspektif Kekerasan Negara: Dua Kasus Dari Surabaya Jawa Timur dan Lombok NTB,' Jurnal Sosiologi Islam, 
3.2 (2013), 28-50.

Gaffar, Abdul, 'Jamaah Ahmadiyah Indonesia (JAI) Dalam Perspektif Kekerasan Negara: Dua Kasus dari Surabaya Jawa Timur dan Lombok NTB', Jurnal Sosiologi Islam, $3.2(2013)$.

Hamdi, Saipul, 'Politik Islah: Re-negoisasi Islah, Konflik, dan Kekuasaan dalam Nahdlatul Wathan Di Lombok Timur,' Kawistara, 1.1 (2011), 1-14.

Hamdi, Saipul, 'Politik Islah: Re-negoisasi Islah, Konflik, dan Kekuasaan dalam Nahdlatul Wathan di Lombok Timur', Kawistara, 1.1 (2011).

Hitti, Philip K., History of The Arabs (New York: Palgrave Macmillan, 2002).

Ida, Rachmah, and Laurentius Dyson. "Konflik Sunni-Syiah dan dampaknya terhadap komunikasi intra-religius pada komunitas di Sampang-Madura." Masyarakat, Kebudayaan dan Politik 28.1 (2015): 33-49.

Jamma, La, 'Dimensi Ilahi dan Dimensi Insani dalam Maqashid al-Syari'ah,' Asy-Syir'ah Jurnal Ilmu Syari'ah dan Hukum, 45.2 (2011), 1251-1270.

Khatibah, 'Penelitian Kepustakaan,' Jurnal Iqra, 5.1 (2011), 36-39.

Mahfudz, Muhammad, 'Konsep Ahlus Sunnah, Tahqiq dan Dirasah Kitab Hujjah Ahl AsSunnah wa al-Jama'ah Karangan K.H. Ali Maksum,'Tesis, Pascasarjana UIN Sunan Kalijaga Yogyakarta, 2010.

Majah, Abi 'Abdillah bin Muhammad bin Yazid bin, As-Sunan vol. 5 (Damaskus: ArRisalah al-'Alamiyah, 2009).

Muhajirin, Ulumul Hadis II (Palembang: Noer Fikri, 2016).

Nasution, Harun, Islam Ditinjau Dari Berbagai Aspeknya I (Jakarta: UI Press, 1985).

Putra, Deni Hardiawan, 'Fenomena Konflik Nahdlatul Ulama dan Salfi Gis Sunnah: Studi Kasus Di Perumahan Griya Indah Serpong, Gunung Sindur, Bogor', Skripsi, UIN Syarif Hidayatullah, 2018.

Rahman, Asjmuni A., Qaidah-Qaidah Fiqh, (Jakarta: Bulan Bintang, 1976).

Syuhbah, Muhammad Muhammad Abu, Kitab Hadis Saheeh yang Enam (Jakarta: Pustaka Lentera Antar Nusa, 1991).

Tasbih, 'Kedudukan dan Fungsi Hadis Sebagai Sumber Hukum Islam,' Jurnal Al-Fikr, 14.3 (2010), 331-341.

Waskito, Abu Muhammad, Mendamaikan Ahlus Sunnah di Nusantara, Mencari Titik Kesepakatan antara Asy'ariyah dan Wahabiyah (Jakarta: Pustaka al Kausar, 2012).

Yuslem, Nawir, Sembilan Kitab Induk Hadis, Biografi Penulisnya dan Sistematika Penulisannya (Jakarta: Hijri Pustaka Utama, 2006). 